\title{
ÉPÜLETVÉDELEM NAGY ENERGIA ELNYELŐ KÉPESSÉGÛ ANYAGOKKAL
}

\section{HIGH-ENERGY ABSORBING MATERIALS FOR OBJECT PROTECTION}

\author{
Kovács Tünde \\ Óbudai Egyetem, Bánki Donát Gépész és Biztonságtechnikai Mérnöki Kar, \\ Gépészeti és Biztonságtudományi Intézet, Cím: 1081, Magyarország, Budapest \\ Népszínház utca 8; kovacs.tunde@,bgk.uni-obuda.hu
}

\begin{abstract}
In the European Union nowadays many terror attacks happen. In the last century designed old, maybe world heritage or critical infrastructure buildings use sometimes for public service offices, was planned without the calculation of the special shock load. The protection of these buildings is impossible by new curtains construction without the townscape changing. The new high-energy absorbing materials can be useful to increase the defence capabilities of these buildings. The new composites and metals foams materials innovated by material science could be suitable.
\end{abstract}

Keywords: critical infrastructure, blast protection, metal foam, composites

\section{Összefoglalás}

Az utóbbi évtizedekben egyre több terrortámadással kellett szembenéznünk az Európai Unióban. Tervezés és méretezés során igénybevételként a robbantások hatását nem vették figyelembe, nem beszélve arról, hogy számos jelenleg közfeladatot ellátó intézménynek helyt adó vagy kritikus infrastruktúra részét képező épület igen régi építésü, esetleg a világörökség részét képezi. Ezen épületek védelme a köré épített védőfalakkal nem biztosíthatók a városkép megváltoztatása nélkül. Az új nagy energia elnyelő képességü anyagok azonban segítséget nyújthatnak ezen objektumok utólagos védelmi képességének növelésében. Az anyagtudomány által fejlesztett új kompozit és fémhab anyagai erre igen alkalmasak.

Kulcsszavak: kritikus infrastruktúra, robbantással szembeni védelem, fémhab, kompozitok

\section{Bevezetés}

Európában, az utóbbi évtizedekben egyre több terrorcselekmény történt. Ezek a támadások különböző módokon valósultak meg, melyek elleni védelmet komplexen biztosítani igen összetett feladat. Ebben a dolgozatban csupán az objektumok robbantással szembeni biztonságának növelési módszereire igyekszem megoldási lehetőséget keresni. Európa nagyvárosai, ahol leginkább számolni kell a merényletek lehetőségével, igen régen épültek. A városok jelentősebb közfeladatot ellátó intézményei általában a városok központjában találhatóak. Ezek az épületek nem keríthetők be, köréjük védőfal nem építhető, mert hiszen az a városképet igencsak rontaná, illetve nem áll rendelkezésre olyan méretü hely, ami ezt lehetővé tenné. Tehát, oly módon szükséges az objektumok védelmét megoldani, hogy 
az építmény falazatát erősítsük meg. Az objektumvédelem magába foglalja az épületek valamint ezek kiszolgáló egységeinek (pl. transzformátor ház, gázfogadó alépítmény) védelmét is. $\mathrm{A}$ robbantással szembeni ellenálló képesség olyan anyagok alkalmazásával valósítható meg, melyek fokozottan képesek az energia elnyelésre.

\section{Nagy energia elnyelő képességü anyagok}

Az anyagtudomány fejlődése során eljutottunk oda, hogy ma már lehetséges fémes anyagokból szilárd habot és fémkerámia kompozitokat előállítani. A fémhaboknak két típusát különböztetjük meg, a zárt és a nyitott cellás változatot. Gyártástechnológiájuk és jellemzőik szerinti felosztásukat az 1. ábra mutatja.

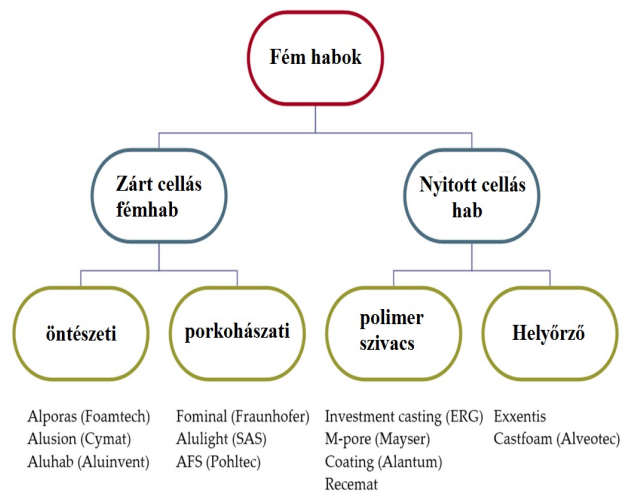

1. ábra. Hab anyagok tipusai és néhány gyártó [1]

A nyitott cellás fémhabok üregei egybefüggőek, vázukat egymáshoz kapcsolódó cellaélek alkotják. Míg a zárt cellás fémhabokban az üregeket cellafalak különítik el [2].

A számos nagy energia elnyelö képességü anyag közül csak a jellemzően, már ipari mennyiségben is gyártható típusokat ismertetem.

\subsection{Nyitott cellás fémhabok}

A nyitott cellás fémhabokra jellemző, hogy igen nagy energia elnyelő képességgel rendelkeznek, tüzállóak, 100\%-ban újrahasznosíthatóak, robbantással szemben is jó csillapító képességgel rendelkeznek. Ezen tulajdonságaik miatt az épületek robbantással szembeni biztonságának növelésére jól használhatóak. Nyitott fémhab metszetét mutatja a 2. ábra. Nyitott cellás fémhabok gyártására több technológiai módszer ismert (pl. kioldásos technológia, percíziós öntés, fémbevonatolásos eljárás) [2].

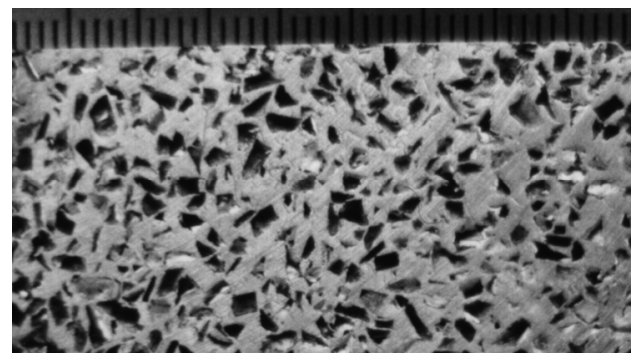

2.ábra Nyitott cellás fémhab [2]

\subsection{Zárt cellás fémhabok}

Zárt cellás fémhabokat habosítással gyárthatjuk, keveréssel, buborékoltatással vagy porkohászi eljárással gyárthatjuk.

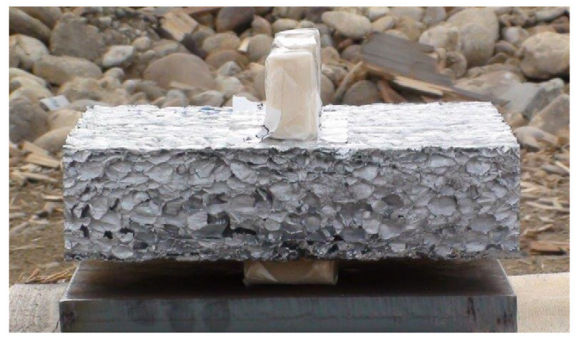

3. ábra. Zárt cellás aluminium hab [1]

A zárt cellás fémhabok mechanikai tulajdonságai közel azonosak a nyitott cellás fémhabokéval, így ezek alkalmazása is előnyös lehet épületvédelmi célokra. 


\subsection{Szintaktikus fémhabok}

A szintaktikus fémhabok olyan fémmátrixú kompozitok, melyekben erősítőként üreges gömbhéjakat alkalmaznak. Ezek a gömbhéjak lehetnek kereskedelmi forgalomban kapható kerámia vagy fém anyagúak és különböző méretüek. A kompozit mátrixanyag legtöbb esetben alumínium vagy egyéb könnyüfém ötvözet. Kis sürüségük miatt könnyü szerkezetekhez, jó energia elnyelő képességük miatt védelmi célokra is alkalmasak.

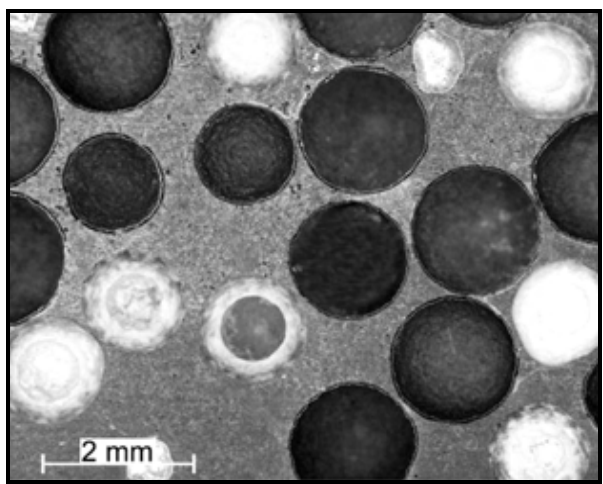

4. ábra. Szintaktikus fémhab csiszolata [3]

\section{Robbanás hatása a falazatra}

\subsection{Robbanóanyagok}

A robbanóanyagok a következő módon csoportosíthatók:

- kis sebességü (gyújtó robbanószer) robbanóanyagok;

- nagysebességü robbanóanyagok.

$\mathrm{Az}$ első robbanóanyagok a kis sebességü robbanószerek csoportjába sorolhatóak. A robbanás valójában az égésnek egy gyors formája, amikor a részek egymás után meggyulladnak, amíg a teljes anyag-mennyiség el nem ég.
$\mathrm{Az}$ ilyen robbanást gyújtórobbanóanyagnak hívják és a reakció sebessége kisebb, mint a hangsebesség. Ezek a robbanóanyagok pl. a lőpor, rakéta üzemanyag, stb. Nagy sebességü robbanószerek nagy mennyiségü gázképződéssel, hőfejlődéssel és túlzottan nagy nyomással járnak. A robbanóanyagokat feloszthatjuk elsődleges és másodlagos robbanóanyagokra is. Az elsődleges robbanóanyagok, karakterisztikájuk szerint érzékenyebben reagálnak, ezek a detonátorok.

Ilyen pl: Mercury Fulminate, Lead Azide, Lead Styphane stb.

Másodlagos robbanóanyagok az elsődleges robbanóanyag által keltett lökéshullámok hatására robbannak fel.

Ezek lehetnek általában a katonai alkalmazású, vagy munkavégzésre szánt robbanóanyagok pl. TNT, RDX, PETN és mások [3].

\subsection{Robbanás okozta igénybevétel}

A hagyományos méretezés során a szélterhelést, a hó terhelést, a földrengést, stb. és ezek együttes hatását, mint extrém terhelést figyelembe veszik a tervezők.

A robbanás által okozott terhelés:

- légnyomás

- állandó nyomás

- talaj lökéshullám

- direkt lökéshullám

- repeszhatás

- gázgyulladás

- tüz okozta terhelés [5]

A jellemző robbanási terheléseket három csoportba osztják, levegőben történő robbanás, síkban történő robbanás és belső térben történő robbanás. Az 5. ábra a síkbeli robbanási modellt mutatja be. 


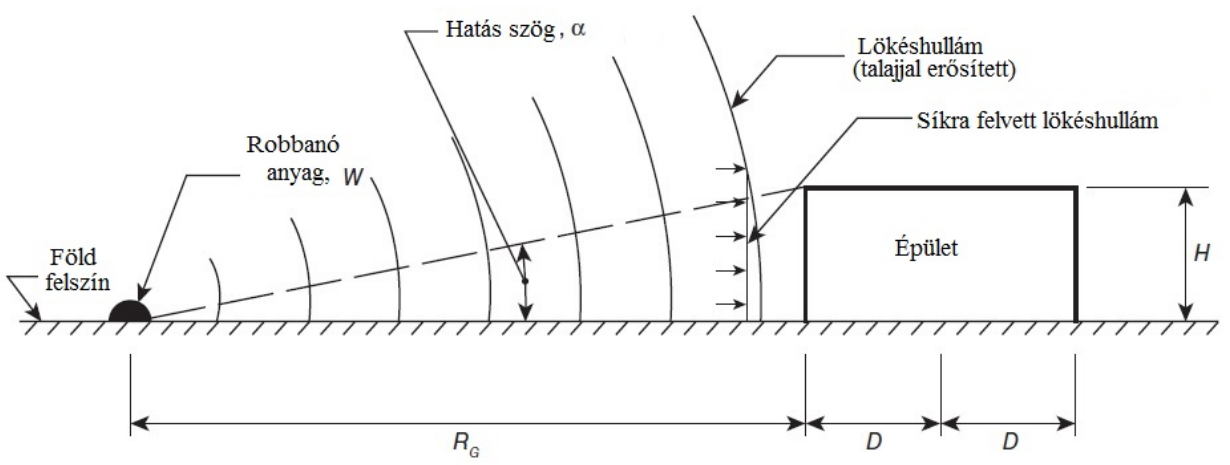

5. ábra Sikbeli robbantás terhelése [5]

\section{Következtetések}

A robbanás által okozott igénybevétel jelentősen eltér a gyakorlatban méretezés alapjául szolgáló igénybevételektől. Azoknál az épületeknél melyek már régebben épültek és köréjük nem építhető védőfal, esetleg kerítés, a falazatra felvitt nagy energia elnyelő képességgel rendelkező anyagréteggel történő utólagos burkolás növelheti a robbantással szembeni ellenálló képességet. A középületek esetében számolni kell az esetleges, épületen belüli belső robbantással szembeni védelemmel is, például ügyféltérben végrehajtott robbanás esetlegesen ne okozzon az épületben szerkezeti kárt. Vagy egy csomagátvizsgáló helyiség esetében kialakítandó robbanással szembeni védelem célját is szolgálhatja az energia elnyelő anyag alkalmazása. A nagy energia elnyelő képességü anyagok száma és típusai igen szerteágazóak az anyagtudomány fejlődésének köszönhetően, viszont ipari méretekben történő gyártás még nem minden típusnál megoldott. A megfelelő robbantással szembeni ellenálló képesség meghatározására még számos kísérlet és számítás szükséges, mely alapján az alkalmazandó anyagok kiválaszthatóak.

\section{Szakirodalmi hivatkozások}

[1] Francisco García-Moreno: Commercial Applications of Metal Foams: Their Properties and Production Materials 2016, 9(2), 85;

[2] Kenesei P., Kádár Cs., Rajkovits Zs., Lendvai J.: Fémhabok elöállitásának módszerei, Anyagok Világa:II. évfolyam 2. szám 2001. április Volume 2 - № 2 - April 2001

[3] Májlinger K., Orbulov I.N.: Hibrid szintaktikus fémhabok szilárdsági jellemzöi. Bányászati és kohászati lapok, Kohászat, 147. évfolyam 2014/1. szám 29-34.

[4] L. Figuli, Š. Jangl, D. Papán: Modelling and Testing of Blast Effect On the Structures. IOP Conf. Series: Earth and Environmental Science 44 (2016)

[5] Nasim Uddin: Blast protection of civil infrastructures and vehicles using composites. Woodhead Publishing Limited, 2010 